\title{
NOTAS ACERCA DA DIMENSÃO FÁLICA DO GOZO NA HOMOSSEXULIDADE MASCULINA
}

\author{
NOTES ABOUT THE PHALLIC DIMENSION OF THE ORGASM IN MALE HOMOSEXUALITY \\ NOTAS ACERCA DE LA DIMENSIÓN FÁLICA DEL GOCE EN LA HOMOSEXUALIDAD MASCULINA
}

\author{
Luis Flávio Silva Couto* \\ Guilherme Pimentel Jordão ${ }^{* *}$
}

\begin{abstract}
RESUMO
Sendo fálica toda lógica sexual, é mister verificar a exclusão do Outro gozo, dito feminino, ao que não resta, sob o discurso sexual, possibilidade de relação, dado o privilégio do Mesmo. O amor homossexual, não obstante, insiste, vinculando, no sexo masculino, mãe e criança, por meio da eleição de objeto narcísica, que projeta o ideal materno sobre o parceiro, enquanto subverte a lógica das identificações. Com o intuito de situar o papel do falo no interior da dinâmica homossexual de relação, orienta-se este artigo, por meio da revisão da teoria freudo-lacaniana sobre o tema, para o estudo do caso de Jean Genet. Genet descreve, em seu Diário de um ladrão, um funcionamento que ilustra o mecanismo da inversão, que parte do tema do amor do próprio rival e avança pelo rebaixamento da insígnia fálica à condição de fetiche, desvelando a particularidade da arquitetura do estilo homossexual de desejar.
\end{abstract}

Palavras-chave: Homossexualidade. Falo. Inversão. Relação sexual. Jean Genet.

\begin{abstract}
Once all the sexual logic is phallic, it becomes necessary to verify the exclusion of the Other orgasm, known as feminine, and consequently, under the sexual discourse, the possibility of relation, given the privilege of the Same. Notwithstanding, homosexual love, insists, attaching mother and child in male sex, through the election of a narcissistic object, that projects maternal ideal on the partner, while subverting the logic of identifications. In order to situate the role of the phallus inside the homosexual dynamics

Texto recebido em 14 de novembro de 2016 e aprovado para publicação em 11 de junho de 2017.

* Pós-doutor em Psicanálise pela Université Paris 8, doutor em Filosofia pela Universidade Federal do Rio de Janeiro (UFRJ), mestre em Filosofia pela Universidade Federal de Minas Gerais (UFMG), graduado em Psicologia pela UFMG. Professor adjunto da Pontifícia Universidade Católica de Minas Gerais (PUC Minas), na Graduação em Psicologia da PUC Minas, com Clínica Psicanalítica II e em supervisão de estágio clínico na área da Psicanálise e Trabalho de Conclusão de Curso XI e XIII; no Programa de Pós-Graduação, leciona disciplinas com ênfase em Psicanálise e em Metodologia. Membro da Associação Mundial de Psicanálise (AMP), Escola Brasileira de Psicanálise (EBP). E-mail: luisflaviocouto@terra.com.br.

** Mestre em Psicologia pela PUC Minas, médico psiquiatra. Tem experiência na área de Psicologia, com ênfase em Psicanálise, atuando principalmente em psicanálise e saúde mental. Atualmente trabalha como psiquiatra na Prefeitura Municipal de Campinas-SP. E-mail: gpjordao@yahoo.com.br.
\end{abstract}


of relationship, this article is guided by a theoretical freudo-lacanian review of that theme, towards the study of Jean Genet's case. Genet describes in his The thief's journal an operation that illustrates the mechanism of inversion, from the theme of love for the rival itself, to that of the relegation of the phallic insignia to the condition of fetish, unveiling the particularity of the architecture of the homosexual style of desire.

Keywords: Homosexuality. Phallus. Inversion. Sexual relation. Jean Genet.

\section{RESUMEN}

Siendo fálica toda lógica sexual, es menester verificar la exclusión del Otro goce, dicho femenino, al que no resta, bajo el discurso sexual, posibilidad de relación, dado el privilegio del Mismo. El amor homosexual, sin embargo, insiste, vinculando, en el sexo masculino, madre y niño, por medio de la elección de objeto narcísico, que proyecta el ideal materno sobre el compañero, mientras subvierte la lógica de las identificaciones. Con el propósito de situar el papel del falo en el interior de la dinámica homosexual de relación, se orienta este artículo, por medio de la revisión de la teoría freud-lacaniana sobre el tema, para el estudio del caso de Jean Genet. Genet describe en su Diario del ladrón un funcionamiento que ilustra el mecanismo de la inversión, que parte del tema del amor del propio rival y avanza por el descenso de la insignia fálica a la condición de fetiche, desvelando la particularidad de la arquitectura del estilo homosexual de desear.

Palabras clave: Homosexualidad. Falo. Inversión. Relación sexual. Jean Genet.

\section{INTRODUÇÃO}

7 al como apontado por Lacan (1957-1958/1999) ${ }^{1}$ em O seminário, Livro 5: as formações do inconsciente (p. 495), o falo, objeto de veneração dos cultos antigos, como representante de uma força transcendente associada à virilidade, assume, no interior da teoria da psicanálise, o valor de significante responsável pela razão do desejo, regulando, desse modo, as relações entre os sexos. Se, por se afigurar desse modo na partilha sexual, como denominador comum, ele torna a lógica sexual fálica por excelência, é impossível mantê-la a distância desse elemento. Toda tentativa de pronunciá-la a dada distância evidencia tão somente a impossibilidade de vir a dizê-la. Excluir o Outro sexo será, logo, um imperativo quando se trata de estabelecer um discurso acerca da relação sexual.

1 A primeira data indica o ano de publicação original da obra e a segunda data indica a edição consultada pelo autor; que só será pontuada na primeira citação da obra no texto. Nas seguintes será registrada apenas a data de publicação original. 
$\mathrm{Na}$ homossexualidade, é digno de nota que o exame de sua estratégia no campo das parcerias verifica a presença de uma tentativa de estabelecer sem restos a relação sexual dita impossível. É como se, reconhecendo desde muito cedo que não há relação, tentasse escrevê-la na forma que é a mais alardeada pelos filósofos, aquela do amor-philia. Inerente à forma universal do amor, esse modo de vincular-se ao semelhante passa a ser dominante no campo do amor erótico, se se quer seguir a inspiração freudiana, mediante o apelo ao mecanismo da inversão. Não obstante pretenda resolver o impasse da não relação, seria ao preço de uma valorização excepcional da dimensão fálica que se verificaria o sucesso da estratégia de enlace homoerótica.

Considerando essa hipótese, pretende-se aqui proceder a uma revisão teórica sobre o tema no interior da teoria lacaniana. Com a ajuda das consideraçóes biográficas de Genet (1986), escritor que insere em sua criação poética o mais íntimo da experiência de sua própria homossexualidade, tentar-se-á encontrar subsídios para esclarecer como se efetuariam as relaçóes entre a homossexualidade, em sua lógica de produção de laço amoroso, e o gozo fálico.

\section{HOMOSSEXUALIDADE E GOZO FÁLICO}

Uma das teses clássicas da psicanálise a respeito da gênese da homossexualidade masculina aponta para um arranjo atinente à dialética fálica, segundo a qual interessa ao sujeito oferecer à sua mãe o falo por ela reivindicado, simbolizado na forma de dom de amor, por meio de uma escolha de objeto narcísica. Nela o falo se converte de signo do desejo em objeto do desejo, processo por meio do qual é alçado ao plano da realidade. Se como signo, o falo sintetizaria o plano geral das relações com o desejo, na dimensão de objeto, estaria destinado ao reducionismo da exigência da presença do pênis, em sua forma mais imediata, na anatomia do parceiro. É preciso considerar, porém, quanto ao papel do falo no contexto da homossexualidade masculina, que sua influência sobre o sujeito segue sendo relativa aos efeitos que por ele serão exercidos sobre o parceiro materno, tese que deverá ser aqui explicada.

O sujeito, nessa posição que corresponde ao objeto do desejo materno, abandonaria a sua dimensão ativa em favor de uma outra que serviria à garantia do amor dali proveniente, e que estaria condicionada por sua estrutura dialética que não é natural, mas decorrência de um arranjo de natureza significante. Tornandose, por tal expediente, ele próprio, objeto narcísico, pode-se reconhecê-lo como objeto que é, e que ao mesmo tempo não é, consideração que implica que será menos próprio, desse modo, para produzir satisfação. Tal impasse, o homossexual tentaria solucioná-lo projetando o seu narcisismo, de modo significativo, no seu parceiro sexual. 
Um tal raciocínio é próprio para estabelecer a relação homossexual no eixo imaginário, que no esquema L é desenhado por Lacan (1956-1957/1994) sobre o segmento a - a' e, como ele mesmo esclarece em $O$ seminário, Livro 4: As relaçôes de objeto (p. 10), nesse eixo, que responde pelo imaginário, está denotada a estrutura de objeto do sujeito, instalada como tal no caráter egoico com que investe os objetos que o atraem, e sobre os quais se mostram fixados. Certamente não se podem resumir as parcerias homossexuais a esse modelo, uma vez que a sua estrutura necessita, também nos termos do esquema $L$, da influência do eixo simbólico (A-S), no qual o Outro paterno deverá oferecer legitimidade às relaçôes postuladas e garantir o acesso aos objetos, que deverão exceder, sob pena de que advenham consequências no plano da psicopatologia, os limites da relação mãe-criança-falo.

Figura 1. Esquema L

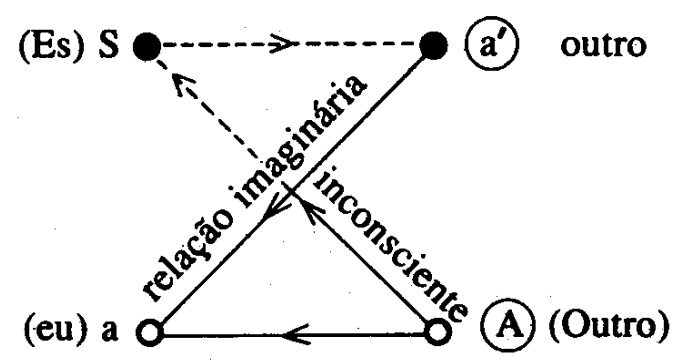

Fonte: (Lacan, 1956-1957, p. 10).

Insinua-se, para tanto, uma falta, que se designa fundamental, conforme ensina Lacan, uma vez que cria um sinal negativo (- ), impossível de positivar, e que se inscreve como castração. A mãe, portanto, tomada como sujeito de falta, com relação a esse objeto privilegiado, instala-a como elemento essencial da relação com a criança que realiza a metáfora do objeto ausente. Parte da estratégia da criança diante da sanha dominadora da mãe é o recurso ao pai como quarto elemento, interditor da equação criança-falo no desejo da mãe. Havendo carência de um pai que exerça tal função no plano simbólico, à criança caberá buscar, em sua defesa, recursos de natureza imaginária, que podem figurar como a dupla mãe, como é o caso do pequeno Hans, ou como o duplo narcísico do parceiro homossexual. Instalar o parceiro narcísico como Ideal fálico seria um modo de tentar saciar o desejo da mãe não limitada pela autoridade paterna, na sua relação com a criança, no sentido de evitar a castração.

O falo, portanto, como decorrência da intervenção da lei paterna, elevado ao estatuto de dom, permite que um sujeito fixe a sua existência sob o signo de um eu-ideal, o qual se fixa desde o ponto do traço unário em que o sujeito se detém como Ideal do eu (Lacan, 1960/1998, p. 823), responsável por ocupar, mas, ao 
mesmo tempo, ocultar o lugar determinante de onde se exerce a influência do Outro materno, que é primordial. O sujeito só toma, pode-se dizer, para si a sua existência conforme é amparado pela transcendência do Outro, de quem se quer fazer objeto na forma do falo.

$\mathrm{Na}$ esfera da teoria do Édipo, a relação do homossexual com a mãe já fora, muito cedo, percebida por Freud (1910/2006), seguido quanto a esse ponto por seus companheiros Ferenczi e Sadger. Sadger, com relação a esses sujeitos, conferia relevância à presença de tendências heterossexuais de forte intensidade durante a infância, sucedidos por intenso complexo de Édipo. Os desejos de morte dirigidos ao pai redundariam num tipo de escolha sexual homoerótica, que manteria, de modo absoluto, a restrição do acesso aos representantes do sexo materno. Diante da rivalidade com relação ao adulto do mesmo sexo, seria o sujeito a este tornado submisso, no que visaria a uma defesa contra a castração, justificada, nos termos de Freud (1909/2006), pela "alta estima sentida pelo homossexual pelo órgão masculino" (p. 101).

O superinvestimento do menino por parte de sua mãe, por outro lado, desvelando a sua falta, que um pai insuficiente não conseguiria resolver, viria culminar num Édipo sustentado pela lei do Outro do sexo feminino, ao que esse jovem, no estilo de Hans, poderia solicitar ao pai, no sentido de liberá-lo da posição de falo materno: "beije-a um pouco mais"; ou, como o paciente de Lacan, de modo análogo, diante da mãe que repudiava o sexo do seu parceiro: "beije-a um pouco menos"; "beije-me em seu lugar, se for preciso" (Lacan, 19561957, p. 372).

No interior de O Seminário: as formaçôes do inconsciente, Lacan (1957-1958), ao seguir as linhas que haviam conduzido o seu comentário acerca do pequeno Hans, constrói para o sujeito homossexual um modelo, desenvolvendo, a partir da explicação freudiana, que atribuíra a sua escolha, nos termos do Édipo, à identificação dele com a própria mãe. Ao se tornar ele mesmo a sua mãe, o homossexual passaria a investir os seus parceiros conforme fora tomado enquanto criança por aquela última; é a teoria presente no texto de Freud (1910) sobre Leonardo.

No contexto da teoria freudiana da identificação, é certamente significativa essa escolha pelo polo materno, uma vez que a identificação primitiva com o pai seria o destino natural, considerando, inclusive, além do seu caráter primário, a circunstância da autorização que lhe concede o pai na conclusão do complexo de Édipo, que, em seu terceiro tempo, confere também ao homossexual a posse do seu órgão, do qual poderá fazer uso, no futuro, com objetos outros que a mãe (que restará interditada). 
Sobre a consideração do Édipo em três tempos, parece importante um breve esclarecimento, já que é sob essa perspectiva que Lacan sintetiza as suas conclusões acerca da gênese da homossexualidade no seu seminário de 1957-1958. Ali, Lacan (1957-1958) postula como o primeiro tempo justamente aquele em que a criança irá se apresentar como falo da mãe, disso podendo sair, tão somente, pela entrada em cena do Nome/não do pai, no segundo tempo, o que o livraria de assumir, diante daquela, a posição de um "assujeito" que encontra, na lei, a possibilidade de vir a ser sujeito (Lacan, 1957-1958, p. 195).

Figura 2. $\mathrm{O}$ "assujeito" em seu encontro com a lei

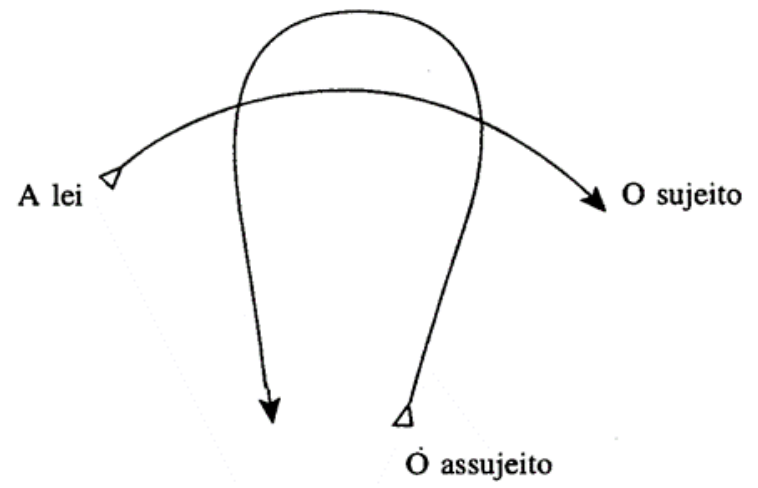

Fonte: (Lacan 1957/1958, p. 195).

Depois disso, introduz o terceiro tempo, em que o pai é o portador legítimo do falo, e somente ele pode, desse falo, fazer dom. É a entrada em cena do pai como detentor do falo que torna este último, para a mãe, um adjeto (objeto que lhe seria exterior), impedindo o seu acesso imediato ao injeto, na forma da criança:

Ao lado do injeto, quer dizer, do objeto injetado, introduzido, Lacan distingue o adjeto, o falo imaginário do qual a mulher está privada. [...] O falo imaginário do qual a mulher estaria privada é, precisamente, muito diferente do falo que poderia ter. É o adjeto o que lhe impede ter acesso ao injeto (Miller, 2009, p. 52).

Seria de uma particularidade no segundo tempo do Édipo que se deduziriam, para Lacan (1957-1958), as consequências para a gênese da homossexualidade masculina, as quais se fariam sentir no curso do seu terceiro tempo, o que justifica que Lacan proponha que, na homossexualidade, estar-se-ia diante de um Édipo pleno e acabado. A particularidade, no segundo tempo, seria a de que a mãe ter-se-ia tornado, ela mesma, responsável por exercer a lei diante do pai, não se deixando privar do adjeto, ao que seria legada ao pai somente a sua indiferença, relativa ao seu papel de agente da lei, o que o deixaria, diante do menino, sob suspeita de não ter. Como afirma Lacan: 
Creio que a chave do problema concernente ao homossexual é esta: se o homossexual, em todas as suas nuances, atribui um valor preponderante ao bendito objeto, a ponto de fazer dele uma característica absolutamente exigível do parceiro sexual, é na medida em que, de alguma forma, a mãe dita a lei ao pai, no sentido como lhes ensinei a distingui-lo. (Lacan, 1957-1958, p. 215).

É claro que isso não significa que o pai não tenha entrado em jogo. Freud, aponta Lacan, havia dito que não era raro que a inversão sexual tivesse sido determinada pela exclusão de um pai demasiadamente proibidor. Mas a posição de um pai de tal tipo pode levá-lo a ser excluído, na dinâmica familiar, fazendo fracassar a sua posição. Isso termina por conduzir a mãe a ditar a lei.

A posição de um pai excessivamente proibidor também pode ser quebrada nos casos, diz ainda Lacan, em que o pai ama demasiadamente a mãe (embora nem sempre isso conduza à homossexualidade do filho). Por seu amor ser demasiadamente dependente dela, ele fica sob a suspeita de não ter o órgão (não se pode esquecer que amar é dar o que não se tem), e ela pode terminar por se tornar, na dinâmica familiar, aquela mediante quem a lei é estabelecida.

Na gênese da homossexualidade masculina, há, ainda, outros casos, entre os quais o pai permaneceu para a criança como um personagem muito distante, não se fazendo presente ou surgindo apenas nos queixumes maternos, muitas vezes acompanhados de manifestações hostis contra ele. $\mathrm{O}$ que faz com que, muitas vezes, o menino passe a ter também um ódio contra o pai, no mesmo sentido em que tal ódio se apresenta no complexo de Édipo considerado normal. Em alguns casos, esse mesmo ódio é transferido para a mãe, num processo a ser esclarecido em análise.

Nos casos em que o pai era, realmente, uma ameaça para o menino, a forma de ele lidar com a situação pode ter sido se identificar com uma mãe que não se deixava abalar, supondo, com isso, para uma incapacidade do trato dele com as mulheres.

A exigência obrigatória da presença do pênis no parceiro, aponta Lacan, corresponde à chave da questão, qual seja, a de que foi a mãe quem ditou a lei ao pai. Daí a questão para o menino: efetivamente, seu pai tem ou não tem o órgão? É isso que é exigido, de seu parceiro, pelo homossexual.

Daí a importância, para a condução de uma psicanálise de orientação lacaniana, a compreensão do que teria sido a dinâmica familiar parental, pois repetindo-a, o homossexual reproduziria, com seus parceiros, a tentativa de desarmá-los e trataria de verificar, na necessária presença do órgão, que estabeleceria como padrão para o seu desejo a posse do falo, signo do poder no jogo do amor, e que viria a dar ensejo à sua identificação primitiva com sua mãe na partilha sexual. 
Esse polo simbólico da identidade própria ao homossexual é aquele que o permite, como se viu, vincular-se à mãe, ao modo como foi investido do lugar de seu objeto, na esteira do narcisismo daquela última, seu Ideal do eu. Imagem desse objeto caro à sua mãe, o sujeito mimetizaria aquilo que perceberia como i (a) em seu eu e conferiria, como tal, ao seu objeto de amor essa mesma divisão. Afirma-se esse ponto em concordância com Lacan (1958-1959/2016), quando ele assinala: "Na homossexualidade, diremos que lidamos com a relação entre a identificação primitiva, simbólica, I, e a identificação narcísica, i (a)" (p. 498).

\section{A ASSOCIAÇÃO COM O UM FÁLICO}

Considera-se aqui, dado o entendimento do Édipo levado a seu termo no homossexual, a tese de que há na homossexualidade a presença do necessário, sob a forma do "Um que diz não". Consequência imediata dessa afirmação é a conclusão de que não haveria homossexualidade apartada do quadrante masculino da sexuação. Neste, o pai morto do mito freudiano (não mais Édipo, mas Totem e tabu) funcionaria, por assim dizer, como limite.

Tomando como referência a definição do Um, conforme se constitui no interior de $O$ seminário 19 de Lacan, considerado este mesmo como preâmbulo dos desenvolvimentos do autor em seu último ensino, em que pese a distinção considerada no interior desse texto entre o Um da identificação, que unificaria os diversos sujeitos sob a égide de um Eros tendente à síntese, e o Um solitário, que diria respeito ao gozo, haveria que ser cogitada a dimensão do pai da exceção como relativa a ambas, junto à primeira na dimensão de uma lógica do atributo e da classe, enquanto, na vizinhança da segunda, pensar-se-ia na dimensão do conjunto.

O Um do quadrante masculino, que funda por sua exceção a função fálica como universal, estabelece-se como elemento de base para o reconhecimento das posiçôes masculina e feminina do ser humano sexuado. Seguindo Lacan (1975/2003), pode-se dizer que "este Um que se sabe sozinho, ponto de real da relação vazia insistente permanece como a hénada inacessível” (p. 547, n. 2). Tal como apontado por Campos (2013), "o Um contempla o inteligível, e dele surge uma hipóstase que é a alma do mundo, como hénada, princípio da formação do mundo sensível". Hénada como unicidade do que é "Um". Sua função é identificar o que há de "Um" no Ser, embora inacessível, como apontou Lacan.

O pai necessário na homossexualidade, a ser considerado na forma da hénada, implica menos a identificação imaginária com o sexo e mais a função que diria respeito à função fálica como o que rege a dialética do desejo, a qual institui o falo como sua razão mais fundamental, ainda que seja sustentado, nesse caso, do 
lado da mãe, que é aquela que detém o poder no jogo do amor. Única exceção à lógica da castração, esse Um, cuja posição aqui pode-se pensar que é ocupada pela instância da mãe fálica, é o que permite circunscrever, sob um mesmo conjunto, elementos diferentes, regidos pela lógica fálica ou da castração.

Sobre a eleição da mãe como representante da lei que funda o conjunto, no plano da homossexualidade, é necessário que se considere a sua eleição, segundo o esclarecimento que aporta Lacan, quando afirma que a hénada, embora seja originária, somente surge secundariamente como um arranjo de saber necessário à estruturação da unidade simbólica. É preciso, portanto, inventar um pai, e mais propriamente um pai morto, que se mantém vivo na forma da lei que interdita o acesso às mulheres, fundando a mãe como a mulher única.

O homossexual mostrar-se-ia, desse modo, a tal ponto defensor da lei paterna, que não ousaria questionar a sua interdição, sequer pelo estabelecimento de laços exogâmicos com o outro sexo. Por outro lado, ser-lhe-ia facultado constituir laço amoroso com todos os representantes do mesmo sexo, o que talvez decorra da exigência de verificação reiterada da castração no semelhante, assim como a ratificação da existência do $\Phi$ do semblante fálico.

Nessa comunhão estabelecida por um fundamento imaginário, é a classe, e não o conjunto que sobressai, ao que se torna necessário verificar, em cada possível parceiro, como condição sine qua non, a presença do órgão dito fálico. Optando por se relacionar com aqueles que têm, o homossexual suspenderia, em sua função, o falo, reconhecendo em seus parceiros muitas vezes somente a sua sombra, representada ao modo do órgão fetichizado. Quanto à sua dimensão simbólica, é possível que o falo continue para sempre localizado do lado da mãe.

Não interessada num Outro que se demonstrasse em falta, a lógica da parceria homossexual certamente não se prestaria a produzir quanto àquele um $S(\mathrm{~A} /)$. Ela se dirigiria, desse modo, para um parceiro que pudesse figurar como $\Phi$, no sentido da perfeição narcísica. Referir-se-ia $\Phi$, então, àquilo que suportaria o significante como $S 1$, mais além do imaginário do atributo que se definiria, de modo diverso, por um $\phi$. Haveria, dessa forma, uma homossexualidade que se poderia delimitar, valendo-se para tanto do uso dos radicais gregos, de um lado no plano do Homos e, de outro, no plano do Heteros. Essa distinção seria apropriada, como é possível divisar, ao comentário acerca da homossexualidade no plano do gozo, que é aquele que interessa à dimensão do Um sozinho.

Seria possível pensar, para o que diz respeito a esses sujeitos, em uma fórmula que definisse o seu tipo de parceria enquanto $\$ \rightarrow \Phi$. O modo de instalação do que denominou parceiro Homos estaria vinculado, desse modo, ao gozo masculino de $\Phi$, ou gozo do idiota, o gozo da masturbação, tal como aponta Lacan (19721973/1985, p. 109). 
De acordo com Miller (2011), Lacan teria definido o gozo fálico como uma das figuras do gozo do Um. Como tal, o gozo fálico não estabeleceria relação com o Outro ou, mais especificamente, esmerar-se-ia em alcançar essa plenitude de satisfação autoerótica, realizando-se por meio do fenômeno masturbatório que, nesse sentido, recebeu de Lacan a referida alcunha de "gozo do idiota". De acordo com Naveau (2017): "Idiota é que o sujeito masculino, no nível mesmo de sua divisão, se satisfaça em ser completado pelo gozo de uma parte do corpo próprio" (p. 143).

O que torna o gozo fálico gozo do idiota é, portanto, essa lógica em que um gozo se encerra no interior da necessidade, tornando-se ilimitado na repetição de si próprio. Considerando essa definição é que seria possível estender o dito gozo do idiota, como tal, à dimensão homossexual.

Talvez essa lógica, que é facilmente atribuível à homossexualidade masculina, também produza efeitos do lado feminino. Como ressaltou Lacan (19711972/2012), na abertura de $O$ seminário 19, só se tem acesso ao Outro sexo pagando o preço da pequena diferença. Essa pequena diferença é significante (p. 16). O falo é seu significado. As homossexuais femininas iriam rejeitá-lo como significante, mas não se dariam conta de que o significante é, na verdade, o gozo, de modo que, tomando, de modo equívoco, o órgão pelo significante, não se aperceberiam de que permaneciam sob a égide do falo, como gozo fálico. Isso, como afirma Lacan (1971-1972), iria deixá-las "numa cegueira total quanto ao que vem a ser o gozo feminino" (p. 17). Tal fato permitiria que sustentassem o discurso sexual com segurança (Lacan, 1971-1972). Não as exilando do seu resto de gozo (feminino), sua concepção da diferença sexual a partir do falo como instrumento, iria aliená-las, ainda que isso, para elas, facilitasse o discurso do amor (Lacan, 1971-1972).

Se a lógica segue sendo, desse modo, fálica, justifica-se que se possa reiterar a prevalência de $\Phi$, como o significante que não tem significado, como parceiro na homossexualidade. Mesmo a tentativa de determinar, conforme se viu, a relação sexual como alheia ao falo, somente pode resultar em sua reiteração como obstáculo à referida relação, que como assinala Lacan (1971-1972), ao se tentar dizer só pode dizer pior. Se há, conforme se viu, um privilégio do mesmo, sob os auspícios da lógica fálica, faz-se importante assinalar que não há acesso por essa via ao Outro, uma vez que a diferença relativa ao sexo, como bem o admitia Lacan, excede a razão diferencial, cujo termo comum é o falo.

Ao se distinguir formalmente Ser e Outro, é importante que se apresente, desse modo, a impossibilidade de associá-los, uma vez que, mais do que o antípoda do Ser, o Outro, considerado em seu estatuto como o não ser, só 
garante a sua existência na exclusão daquele primeiro, o que seria idêntico para o Outro quando tomado da perspectiva do Ser. No campo das relação entre os sexos, poder-se-ia dizer que se, em concordância com Lacan, a mulher ou o feminino é da natureza do Outro, o homem, consequentemente, será definido como aquele que é sempre o Mesmo: "Se é possível opor o homem e a mulher, é como Mesmo e Outro" (Miller, 1989/2011, p. 103, tradução nossa). ${ }^{2}$ Levada à sua radicalidade, tal definição conduzirá ao entendimento de que toda relação implicará o privilégio do Mesmo, enquanto do Outro reivindicará a exclusão.

Tal dialética entre o Mesmo e o Outro, no seio das relações entre os sexos, Lacan (1972-1973) faz com que figurem num comentário que se registra no interior do Seminário Mais, ainda, e que aparece como segue:

O que eu disse há pouco da coragem, da paciência da alma em suportar o mundo, é o verdadeiro correspondente do que faz Aristóteles desembocar, em sua procura do bem, no seguinte: que cada um dos seres que estão no mundo só pode se orientar para o maior dos seres ao confundir seu bem, seu próprio bem, com aquele mesmo

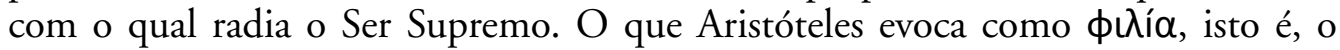
que representa a possibilidade de um liame de amor entre dois desses seres, pode também, ao manifestar a tensão para o Ser Supremo, se revirar daquele modo que exprimi - é pela coragem em suportar a relação intolerável ao ser supremo que os amigos, os фí̉ol, se reconhecem e se escolhem (Lacan, 1972-1973, p. 114).

Ao identificar o Bem universal com o bem particular, Aristóteles concebe o amor (philia) como aquilo que aspira ao sumo bem (áristos). Portanto, já na pena do Estagirita, a finalidade do amor apontaria para o Bem, que é idêntico para todo e qualquer homem, e, desse modo, pressupóe a conjunção entre os iguais. $\mathrm{O}$ amor, desse modo, nos termos de Aristóteles (1996), seria igualdade, ou mesmo unidade, ao que cabe a consideração da seguinte afirmação contida na Ética a Nicômaco (IX, 1166 b): "O extremo da amizade [philia] é comparado ao amor que sentimos por nós mesmos". A tal afirmação, juntar-se-ia outra, colhida da Ética a Eudemo (Aristóteles, 2009), que ressalta:

Mas é uma alegria ainda maior provar juntos os prazeres mais requintados e divinos. A causa dessa felicidade é que é sempre mais doce contemplar-se a si mesmo através de um homem de bem, melhor ainda que você mesmo. Por vezes, é um simples sentimento, às vezes um ato, às vezes qualquer outra coisa que reúne os coraçōes (Aristóteles, 2009, tradução nossa). ${ }^{3}$

As duas passagens citadas reforçam a afirmação segundo a qual o amor, como narcísico, aponta para a contemplação do horizonte fálico da própria existência, interessando ao amante obter, por meio do seu amado, aquilo que um dia foi

2 "Si se pueden oponer el hombre y la mujer es más bien como lo Mismo y lo Otro [...]."

3 “Mais c'est un bonheur bien plus vif encore que de goûter ensemble des plaisirs plus relevés et plus divins. La cause de cette félicité, c'est qu'il est toujours plus doux de se contempler soi-même dans un homme de bien, meilleur encore que vous. Parfois, c'est un simple sentiment, tantôt un acte, tantôt quelqu'autre chose qui réunit les coeurs." 
ou que desejou ser, de modo particular na relação com o desejo do Outro. Esse traço que é muito claro na perspectiva psicanalítica da homossexualidade aponta, sem dúvida, também para a consideração de que o amor é, em si mesmo, universalmente homossexual.

Não obstante, parece que, se pretende o amor dirigir as almas no sentido da unidade, no plano dos corpos, essa mesma união restará interditada. Essa impossibilidade de cópula no domínio do real dos corpos conduz o gozo na direção do similar, de modo que se possa garantir, por meio do amor, a emergência do verdadeiro no interior do real. Esse verdadeiro se permite figurar por meio do Um do falo, instrumento que possibilita velar a ausência da relação sexual, de cuja responsabilidade pode ser, ele mesmo, de modo imediato, imputado.

\section{A ESTRATÉGIA DA INVERSÃO}

A ideia que associa a homossexualidade masculina e o seu modo de produzir laço amoroso como tributária das relações que se estabelece com o falo advém, em grande medida, dos escritos de Freud, e emerge de modo aparentemente muito direto da sua descrição de 1922, no texto Alguns mecanismos neuróticos no ciúme, na paranoia e no homossexualismo. A vinculação aos mecanismos do ciúme e da paranoia permite, além disso, neste interessante artigo, teorizar de modo preciso o conceito de inversão, antes em Freud já associado ao mecanismo da homossexualidade e que, então, torna-se mais preciso sob a utilização do termo alemão Wendung (inversão, no sentido de mudança de direção).

A descrição feita ali por Freud dá conta de uma situação em que um menino, intensamente ligado à sua mãe no plano libidinal, é tomado por certa rivalidade com relação aos seus irmãos mais velhos. Caso venham a cair sob influência do recalque, esses impulsos agressivos são convertidos em amor homossexual por esses objetos privilegiados. Seguindo um raciocínio parecido, um outro exemplo acentua, para além da conversão do ódio em amor, a característica especial do objeto, ocorrência que precisa ainda mais o mecanismo descrito em sua relação com a dinâmica da relação entre o sujeito e o Outro materno:

Esse novo mecanismo de escolha homossexual de objeto - sua origem na rivalidade que foi sobrepujada e em impulsos agressivos que se tornaram reprimidos - combina-se às vezes com as condiçôes típicas já familiares para nós. Na história dos homossexuais ouve-se amiúde que neles a mudança se efetuou após a mãe ter elogiado outro rapaz e tê-lo estabelecido como modelo (Freud, 1922, p. 246).

Essa inversão (Wendung) assinala que, diante da tentativa de se manter como objeto passivo no desejo da mãe, um sujeito em vias de se tornar um futuro homossexual, reconhecendo a presença do outro que lhe faz concorrência junto à sua parceira originária, trata de convertê-lo em seu objeto. Ao lhe emprestar 
características suas, tão amáveis quanto as suponha, converte esse objeto em um duplo seu (eu-ideal), e isso o tornará capaz de amá-lo a partir da posição da mãe, com a qual se identifica. Importante, mais além de suas implicações sobre a dinâmica edípica, é que, no plano da dialética do desejo, o sujeito que se julgava amado será obrigado, diante do valor atribuído a este objeto rival, a converter-se em amante.

Genet (1986), em Diário de um ladrão, romance originalmente publicado em 1949, descreve um mecanismo semelhante em determinada passagem, o que leva a observar que, ressalvadas as diferentes formas como denomina os seus personagens, parece aproximá-los da apresentação feita por Freud, da maneira mais ilustrativa. Stilitano, vagabundo venerado por Genet, em algum momento, resolve trocá-lo por Robert, rapaz junto com quem realizava, ambos, pequenos furtos de outros homossexuais. A situação em que se vê preterido, Genet (1986) assim a descreve:

Tinha ciúmes dos meus dois amigos. Enfim, como Robert gostasse das mulheres, sorria para todas elas. Era amado. Por causa disso, eu o sentia com Stilitano não contra mim, mas fora do meu alcance. A fim de que, sendo a sua lindeza maior do que a minha, the deu as minhas roupas. Desenvolto, sorridente, Robert as usava. Eu só possuía uma calça, um paletó e camisas rasgadas. Arquitetei medíocres vinganças contra Stilitano (Genet, 1986, p. 134).

Algumas páginas adiante, seguindo a indicação de White (2003), encontramos a descrição de como, pela primeira vez se lançando em assalto sobre um homossexual, Genet adquiria as virtudes do seu rival Robert, a ponto de assumir diante da sua vítima uma posição viril e ativa que, é certo, não correspondia àquela que era a sua. No contexto da sua relação com Stilitano, a crueldade com que efetuou o assalto tinha a intenção de alçá-lo à altura do seu rival Robert.

De modo semelhante, o relato de sua relação com Armand, em que está implicado o mesmo Robert, diante da admissão deste de que, referindo-se ao primeiro: "[...] sou tua mulherzinha mesmo?" (Genet, 1986, p. 192), o narrador acabaria por solucionar o que brotava como conflito e angústia, visto que era esse mesmo papel o que ambicionava para si junto a Armand, nos seguintes termos: "Hoje em dia eu talvez resolvesse tamanha angústia trabalhando para juntar aqueles dois homens a quem amava: um pela sua força, o outro pela sua graça” (p. 195).

Estaria posto nesses eventos algo do segredo da homossexualidade de Genet, que portava em seu interior, de acordo com o que compreende Sartre (1967), a necessidade de, em concordância com a tese de Freud, antes aludida, uma vez que era impossível que se fizesse amado, que se tornasse amante. Ele dava, como se pôde ver, o seu amor ao seu semelhante, objeto de sua admiração, tal como a 
ele se apresentava, numa dinâmica que era, de acordo com o que nos esclarece o autor, a seguinte: "Adora todos esses meninos belos e cruéis que o dominam sem misericórdia, submete-se servilmente a seus desejos, faz-se libertino; já que não pode ser amado, será o amante (Sartre, 1967, p. 91, tradução nossa). ${ }^{4}$

Essa essência de criança mal-amada, filho abandonado, como foi, por sua mãe, parece ter marcado para Genet o lugar desse sujeito que necessitou, desde a juventude, inventar uma ficção relativa ao objeto para sustentar a condição dita de amante, que ama os seus sedutores delinquentes, identificando esse viés com um suposto legado materno. Significativo desse contexto é a cena descrita por Genet (1986), que vem reforçar o plano das identificações até aqui sublinhado, na qual o narrador se dedica a fantasiar um encontro com a sua mãe. O relato aparece na sequência da sua detenção pela polícia, enquanto errava como vagabundo pela Espanha:

"É uma ladra", pensei. Ao afastar-me dela, uma espécie de sonho agudo, vivo dentro de mim e não na beira do meu espírito, me levou a pensar que talvez fosse minha mãe que eu acabava de encontrar. Nada sei dela, que me abandonou no berço, mas esperei que fosse aquela velha ladra que mendigava de noite. (Genet, 1986, p. 19).

Situando-se como Ideal (I) em meio às insígnias que apareceriam em resposta à demanda colocada ao Outro, o sujeito obteria, por meio desse expediente, a miragem que comporia o seu eu-ideal, o qual, nesse domínio, colonizaria a figura do parceiro do amor: para um vagabundo, uma mãe ladra e um amante ladrão. É o equivalente de $\Phi$, como objeto do desejo do Outro, que nesse lugar se acomoda, tomando por representante a imagem do parceiro.

Genet, como comenta Sartre (1967), teria de se valer da imagem de seus semelhantes para que realizasse o seu ser, tornando-se, a seus próprios olhos, objeto de desejo. Esse modo de constituir laço na esfera sexual permite que o sujeito assim concernido possa dizer, mediante a significação fálica a que submete o outro, algo acerca de si mesmo e de seu sexo:

Cada um dos homens aos que Genet se entrega se converte no representante variável e imperfeito desse Outro idêntico que Genet quer ser para si. Amando essa bela indiferença de todo seu corpo e toda sua alma, o menino abandonado realiza seu sonho impossível de ser amado. Pois posto que ele é o Outro, é ele, ele somente, o amado no Outro (Sartre, 1967, pp. 100-101, tradução nossa)..$^{57}$

Sendo a visada dessa forma de homossexualidade tornar-se esse objeto reluzente, digno do amor do Outro, é importante que fustigue o outro para que

4 "Adora a todos esos niños bellos y crueles que le agobian sin misericordia, se somete servilmente e sus deseos, se hace libertino; ya que no puede ser el amado, será el amante."

5 "Cada uno de los hombres a los que Genet se entrega se convierte en el representante variable e imperfecto de ese Otro idéntico que Genet quiere ser para sí. Amando esa bella indiferencia de todo su cuerpo y toda su alma, el niño abandonado realiza su sueño imposible de ser amado. Pues, puesto que él es el Otro, es él, él solo el amado en el Otro." 
lhe dê provas do seu valor fálico ou da sua própria castração. Se, na perspectiva homossexual, importaria ressaltar a relação do falasser sexuado com o $\Phi$ maiúsculo, naquilo que diz respeito ao gozo fálico e à sua vinculação com a satisfação do órgão, exigido, como tal, no corpo do parceiro, tal circunstância permite que seja, nesse ponto, a homossexualidade aproximada da visada da histérica, que, no esquema que propõe Lacan, no andar inferior da tábua da sexuação, vincula-se, também ela, a este mesmo $\Phi$ maiúsculo.

Relativo ao gozo da histérica, Naveau (2017) indica que nele importa interrogar o mestre acerca de sua capacidade de sustentar o gozo um, que é o gozo fálico. "Neste nível, o $S_{2}$, precisa Lacan, vale enquanto ele representa o pênis em ereção. Nesse sentido, para dizer a coisa assim, o mestre, $S_{1}$, é inevitavelmente ligado a seu signo, $S_{2}$ ” (Naveau, 2017, p. 165). Esse desafio imposto ao mestre pela histérica e que sustenta a sua relação com seus parceiros do sexo masculino, semelhante àquela que antes se observou com relação ao homossexual, traduz o seu questionamento relativo à castração bem como à disposição do mestre para enfrentá-la.

Retornando ao herói de Genet, aquele mesmo Stilitano viril a quem faltava uma mão e que trazia um cacho de uvas de imitação fixado por baixo das calças, Genet (1986) anota, à certa altura, observaçôes acerca das razões do amor que lhe dedicava. Em primeiro lugar: "Foi pelo insidioso poder desse cacho, creio eu ainda, que me apeguei a Stilitano" (Genet, 1986, p. 51). Logo em seguida, na mesma página, explica:

Apraz-me ver em Stilitano um pederasta que se odeia [...] Pensando com mais vigor, a ideia de que Stilitano tenha comprado uma chaga postiça [o cacho de uvas] para aquele nobre lugar, a fim de salvar do desprezo a mão amputada, era ainda mais perturbadora [...] (Genet, 1986, p. 51).

Em contraste com as observações feitas acima, o autor acrescenta esta anotação, que conclui o relato do qual ressalta um insuspeitado cenário masoquista, em que Genet goza de ser agredido por seu companheiro enquanto acaricia junto ao seu rosto o dito cacho de uvas: "A qualidade do meu amor exigia dele [Stilitano] que desse provas de sua virilidade" (Genet, 1986, p. 52). E conclui por conferir a seu objeto de amor o lugar mais digno, capaz mesmo de tirá-lo do desejo da "abjeção moral", nos seguintes termos:

A audácia daquela vida de ladrão - e a sua luz - nada teria significado se Stilitano a meu lado não tivesse sido a prova dela. A minha vida se tornava magnífica segundo os homens, já que eu possuía um amigo cuja beleza se prende à ideia de luxo. Eu era o criado que deve conservar, tirar-lhe o pó, dar-lhe brilho, encerá-lo, um objeto de grande preço, mas que pelo milagre da amizade me pertencia. (Genet, 1986, p. 55). 
Como observa White (2003), Stilitano, único personagem em Diário de um ladrão que, aparentemente, não cede à tentação homossexual, é propositalmente retratado numa patética cena na sala de espelhos, num excurso de um relato de sedução no qual a mesma personagem tem ressaltada a sua virilidade. Após aquela espécie de castração simbólica, Genet recobraria a cena, que parece tomar maior importância pelo fato de contemplar a recuperação das virtudes viris de seu parceiro. Somente às expensas da verificação da presença do órgão é que se fez possível que o valor desse outro humilhado pudesse novamente ser reconhecido. Mais do que isso, de acordo com White (2003), o rebaixamento que se impôs a Stilitano após a situação com os espelhos, franqueia a Genet o acesso ao pênis do companheiro, até então proibido:

[...] Sob os meus dedos, apenas roçando, senti que ele estava tendo uma ereção.

- Tá gostando?

Não respondi. Para quê? [...] Murmurei rapidamente:

- Gosto de você (Genet, 1986, p. 256).

Uma tal observação permite acompanhar as elaborações de Millot (2004), naquilo que a autora ressalta a escolha homossexual como uma recusa com o ciclo da reprodução da vida, que se pode interpretar como a mortificação, que concorda com a tese da identificação ao falo morto, e que tem por consequência a ideia de que: 'O amor pederasta é uma delegação, uma procuração: o amado 'reproduz' o amante, mas é a única reprodução na qual ele consente" (Millot, 2004, p. 71). Essa ideia da reprodução de si mesmo no outro convoca a compreensão de que, no amor sexual, cada qual estaria entregue à própria solidão, "pois o duplo não deixa lugar para a alteridade do desejo” (Millot, 2004, p. 80). Essa recusa viria ao lado de um certo menosprezo pela virtude que sacraliza o falo como insígnia paterna, tornando-o, dessa maneira, apenas um fetiche:

Ridicularizá-la, embora a exaltando, é esta a dupla posição sustentada pelo homossexual: zombar de seus atributos enquanto símbolos da fecundidade, do desejo irresistível de perdurar uma vida desprezada [...] mas magnificar esses mesmos atributos quando estão livres de sua função reprodutora, desprovidos de sua finalidade, apreciados apenas em sua qualidade de objetos, pesados, avaliados, medidos de acordo com seu valor de gozo. (Millot, 2004, p. 71). 
Esses pontos, que caracterizam no discurso da personagem de Genet a incidência dessa lógica de inversôes, implicam que se possa estabelecer entre os contrários, que são a recusa da castração, por um lado, e sua aceitação na forma do gozo mais abjeto, de outro, uma identidade (Millot, 2004). É dessa lógica ressaltada pela autora como a do "quem perde ganha" que, não obstante a derrisão defina a sua lógica, o culto fálico antes descrito poderá, como parece sugerir o texto de Genet, para além dessa degradação, aportar uma virtude salvadora.

\section{O PARCEIRO FALO E A RELAÇÃO-SEXUAL}

A função fálica, atuando no plano das relações, supriria a relação sexual impossível, representada pelo laço incestuoso que a castração interdita, fundando uma possível equivalência entre A/ e $\Phi$ (Castanet, 2014). Sendo da ordem do necessário, a presença do gozo fálico, como ela exija a não consideração da ocorrência do Outro gozo, não faz mais do que se reiterar pelo expediente da linguagem, redundando, desse modo, na ocorrência da não relação sexual: "Por causa de ele falar, o tal gozo, a relação sexual, não há" (Lacan, 1972-1973, p. 83).

Venha ele a funcionar como incidência do simbólico no real, produzindo um furo, ou como real que invade o plano do simbólico, ao falo caberá a interrupção da lógica da necessidade, no plano da satisfação, em favor da castração. Qualquer que seja a definição precisa, uma vez que em Lacan podem ser encontradas ambas, o que elas traduzem, quando se pensa acerca de seus resultados, estará em concordância com aquilo que Lacan (1975-1976/2007) assim define: "O falo é a conjunção do que chamei de esse parasita, ou seja, o pedacinho de pau em questão, com a função da fala" (Lacan, 1975-1976, p. 16). Assim, o falo delimita um furo, por meio do qual estabelece os critérios do significado em termos de fálico e não fálico, termos que reproduzem, em certa medida, a lógica masculina do todo e da exceção.

Para verificar a ausência de relação sexual, a função fálica $(\Phi x)$ opera no sentido de que, se por um lado, há o Um da exceção, não submetido à função $\Phi$, resta aos demais serem todos submetidos à função $\Phi(\vee x \Phi x)$, ainda que de modo não todo. Seguindo tal raciocínio, reconhece-se que a relação aqui não se verifica, posto que somente seria concebível quando admitida a não equivalência entre seus termos. A relação, portanto, seria possível apenas entre os polos $\exists x \overline{\Phi x}$ e $\forall x \Phi x$, ou, em outros termos, entre o Outro e o sujeito castrado. Desse modo, se a parceria homossexual verifica a existência da relação sexual, interessa também, em seu caso, limitá-la à situação mãe (Outro)-criança, em que o sujeito se mostra como complemento do Outro. A parceria homossexual se apresentaria, portanto, numa articulação entre o necessário e o impossível. 
O real do sexo, desse modo, sendo o real da existência do Outro sexo, dele só pode resultar a não relação. Admitir a não relação pode ser, paradoxalmente, o corolário da invenção de um modo de relação que, no campo do real, se faz pela entrada em cena do falo $(\phi)$, que produz um sujeito adequado ao Ideal do Outro materno $(\Phi)$. Se a homossexualidade verifica a não relação, conforme concebe a possibilidade da relação, é por essa mesma visada que se faz representante da estrutura do laço amoroso, o qual somente se concebe enquanto conjunção entre máscaras. Os sujeitos envolvidos tomam seu modelo dessa relação primária com o parceiro materno, na forma de $\Phi$, com que se identificam, seu complemento sendo, a um só tempo, aquele com o qual se reúnem para fazer face ao Outro, assim como o que aparece a esse mesmo Outro como objeto de gozo $(\phi)$.

Situando a vertente masculina da homossexualidade sob a égide do falo, é sugestiva a observação encontrada em Miller (2015), a qual permite sintetizar as condições da escolha do parceiro, nesse registro, sob a cifra do $\Phi(a)$. Como responderia a pelo objeto da fantasia, sua presença, como semblante, viria aí garantir o encontro do sujeito com o gozo de $\Phi$ e seu caráter de esplendor narcísico. É possível, seguindo esse mesmo raciocínio, uma vez que a marca do desejo homossexual passaria pelo rechaço do corpo feminino, posicionar um $\phi$ em substituição ao $a$ entre parênteses, o que evidenciaria as intenções nesse modo de gozo, no que ele intentaria evitar da presença do Outro - S(A/) -, ainda que fosse, como tal, aquilo com que se depararia qualquer sujeito no plano da demanda de amor. Essa elaboração recobraria, nos termos do último Lacan, aquilo que, no seminário de 1953-1954, está descrito como drama do desejo homossexual, que consistiria em, junto ao outro, dedicar-se eternamente à busca de um desejo que não seria outro que o seu próprio: "Aí reside o drama dessa paixão ciumenta, que é também uma forma da relação intersubjetiva imaginária" (Lacan, 1953-1954/1986, p. 253). Considera-se que, nesse ponto, a hipótese de Lacan pode ser ratificada por Genet. 


\section{REFERÊNCIAS}

Aristóteles. (1996). Ética a Nicômaco. São Paulo: Nova Cultural. (Os pensadores)

Aristóteles. (2009). Morale a Eudeme: Livre VII. Paris: Librairie Philosophique de Ladrange. Recuperado a partir de http://remacle.org/bloodwolf/philosophes/ Aristote/eudeme7-12.htm

Campos, S. (2013). Yadl'Un e suas implicaçōes para a psicanálise. In Haun: Leituras do ... ou pio, 19 Seminário Internacional da Escola Brasileira de Psicanálise. Buenos Aires: EBP. Recuperado a partir de http://www.ebp.org.br/ haun/boletins/009.asp

Castanet, H. (2014). La perversión. Buenos Aires: Grama.

Freud, S. (1909). Análise de uma fobia em um menino de cinco anos. In J. Salomão (Trad.), Edição standard brasileira das obras psicológicas completas de Sigmund Freud (Vol. 10, pp. 11-133). Rio de Janeiro: Imago, 1996. (Publicado originalmente em 1909).

Freud, S. (1910). Leonardo Da Vinci e uma lembrança de sua infância. In J. Salomão (Trad.), Edição standard brasileira das obras psicológicas completas de Sigmund Freud (Vol. 11, pp. 67-142). Rio de Janeiro: Imago, 2006. (Publicado originalmente em 1910).

Freud, S. (1922). Alguns mecanismos neuróticos no ciúme, na paranóia e no homossexualismo. In J. Salomão (Trad.), Edição standard brasileira das obras psicológicas completas de Sigmund Freud (Vol. 18, pp. 233-248). Rio de Janeiro: Imago, 2006. (Publicado originalmente em 1922).

Genet, J. (1986). Diário de um ladrão. Rio de Janeiro: Rio Gráfica.

Lacan, J. (1953-1954). O seminário, Livro 1: os escritos técnicos de Freud (3a ed.). Rio de Janeiro: Jorge Zahar ,1986. (Publicado originalmente em 1953-1954)

Lacan, J. (1956-1957). O seminário, Livro 4: as relaçôes de objeto. Rio de Janeiro: Jorge Zahar, 1994. (Publicado originalmente em 1956-1957).

Lacan, J. (1957-1958). O seminário, Livro 5: as formaçôes do inconsciente. Rio de Janeiro: Jorge Zahar, 1999. (Publicado originalmente em 1957-1958).

Lacan, J. (1958-1959). O Seminário, Livro 6: o desejo e sua interpretação. Rio de Janeiro: Jorge Zahar, 2016. (Publicado originalmente em 1958-1959). 
Lacan, J. (1960). Subversão do sujeito e a dialética do desejo no inconsciente freudiano. In J. Lacan, Escritos. (pp. 807-842). Rio de Janeiro: Jorge Zahar, 1998. (Publicado originalmente em 1960).

Lacan, J. (1971-1972). O seminário, Livro 19: .. ou pior. Rio de Janeiro: Jorge Zahar, 2012. (Publicado originalmente em 1971-1972).

Lacan, J. (1972-1973). O seminário, Livro 20: mais ainda (2a ed.). Rio de Janeiro: Jorge Zahar, 1985. (Publicado originalmente em 1972-1973).

Lacan, J. (1975). ... ou pior, relatório do seminário de 1971-1972. In J. Lacan, Outros escritos. Rio de Janeiro: Jorge Zahar, 2003. (Publicado originalmente em 1975).

Lacan, J. (1975-1976). O seminário, Livro 23: O sinthoma. Rio de Janeiro: Jorge Zahar, 2007. (Publicado originalmente em 1975-1976).

Miller, J.-A. (1989). Los divinos detalles. Buenos Aires: Paidós, 2011. (Publicado originalmente em 1989).

Miller, J.-A. (1998-1999). La experiencia de lo real en la cura psicoanalítica. Buenos Aires: Paidós, 2011. (Publicado originalmente em 1998-1999).

Miller, J.-A. (2009). Perspectivas do Seminário 5 de Lacan. Rio de Janeiro: Jorge Zahar.

Miller, J.-A. (2015, julho). Sobre o Gide de Lacan. Opção Lacaniana Online: nova série, ano 6 (17), 1-35. Recuperado a partir de http://www.opcaolacaniana. com.br/pdf/numero_17/Sobre_o_Gide_de_Lacan.pdf

Millot, C. (2004). Gide, Genet, Mishima: inteligência da perversão. Rio de Janeiro: Companhia de Freud.

Naveau, P. (2017). O que do encontro se escreve: estudos lacanianos. Belo Horizonte: EBP.

Sartre, J.-P. (1967). San Genet: comediante y martir. Buenos Aires: Losada.

White, E. (2003). Genet: uma biografia. Rio de Janeiro: Record. 